\title{
4
}

\section{Do International Organizations Influence Domestic Policy Outcomes in OECD Countries?}

\author{
Linda A. White
}

This chapter examines the role that transnational and supranational actors and organizations, and particularly international organizations (IOs) play in promoting domestic policy change in areas related to family policy in OECD countries. Existing research demonstrates a mixed record in terms of transnational and international non-state actors' influence on domestic policy-making generally, particularly in the Global North (Avdeyeva, 2010; Kollman, 2009; Paxton, Hughes, \& Green, 2006; Zwingel, 2012). This chapter argues that international norms in the areas of gender equality in general and family policy in particular are diffusing to domestic policy processes rather unevenly across OECD countries (see also Linos, 2011; White, 2011, 2014, 2017b). For countries that are part of the European Union (EU), this supranational organization has been an important driver of social policy related to the family and balancing work and family life. It can set common principles and standards in the form of directives on member countries, and the European Court of Justice (ECJ) can rule on member countries' compliance with EU laws (see also Jenson in this volume). Most recently, the European Council and European Parliament enacted a Work-Life Balance Directive (PE-CONS 20/19) in 2019 based on a 2017 European Commission proposal that set even higher minimum standards in member countries regarding paternity leave, parental leave, carers' leave, and flexible work than the 2010 Council Directive on parental leave (Council

\footnotetext{
L. A. White $(\varangle)$

University of Toronto, Toronto, ON, Canada

e-mail: linda.white@utoronto.ca 
Directive 2010/18/EU). For example, the Directive requires member states to provide paternity leave for at least ten working days after a child is born paid at a level equivalent to maternity leave provisions. It also requires member governments to expand parental leave from at least four months unpaid to paid and expand the number of months that are non-transferable between parents from one to two months and to permit it to be taken in flexible forms, such as on a part-time basis. Member governments are also required to permit flexible work arrangements for parents and caregivers for children up to age eight. Finally, the Directive requires either paid or unpaid leave of up to five working days per year for someone to provide personal care or support to a relative, or to a person who lives in the same household as the worker, and who is in need of significant care or support for a serious medical reason.

Yet, country governments within the EU and certainly outside of the EU still exercise considerable autonomy in taking up ideas of IOs. A significant constraint on IO influence is the willingness of country national governments to respond to international norms and standard setting and to regard IOs as sources of legitimate policy advice. Even if policy ideas become normative at the international level, there can be varying levels of receptivity to those ideas domestically. At the same time, while IOs may not directly affect domestic decision making, they can, through their reports and conferences, facilitate the spread of ideas of best practices among member countries. IOs can thus help to create norms and transmit those norms to domestic policy actors who then advocate for their adoption. Generally, then, IOs are not as much authoritative actors as epistemic actors who contribute to policy ideas, but with policy implementation remaining the responsibility of domestic political actors and coalitions.

The chapter begins by reviewing the extant literature on supranational actors generally and IOs particularly as sources of authority and of domestic policy influence. It then focuses more specifically on the track record with regard to gender equality in general and family policy and programs in particular.

\section{International and Transnational Influences on Domestic Policy Making: A Review of the Literature}

The literature on transnational policy diffusion points to myriad sources of domestic policy ideas, including international organizations (IOs) (Barnett \& Finnemore, 2004), transnational advocacy networks (Keck \& Sikkink, 1998), 
epistemic communities (Haas, 1992), networks of state actors (Slaughter, 2004), and government-to-government transfer of policy ideas (Marsh \& Sharman, 2009). These myriad actors and institutions are involved in international regime setting: that is, in establishing "social institutions consisting of agreed upon principles, norms, rules, procedures and programs that govern the interactions of actors in specific issue areas" (Zwingel, 2012, p. 116).

International organizations such as the European Union (EU), International Labour Organization (ILO), Organisation for Economic Cooperation and Development (OECD), and the United Nations (UN), particularly the UN Educational, Scientific, and Cultural Organization (UNESCO), the Office of the High Commissioner on Human Rights (OHCHR), and the United Nations Children's Fund (UNICEF), along with transnational actors and activists have been key players in transmitting and supporting ideas around democracy, human rights, and labor standards. Those ideas have become embedded in a dense array of laws and conventions and supported by formal laws and institutions (Barnett \& Finnemore, 2004; Goodman \& Jinks, 2013; Greenhill, 2010; Klotz, 1995; Payne, 2001; Simmons, Dobbin, \& Garrett, 2008).

IOs and other actors and institutions have also been key in promoting gender equality in general, including voting rights, gender quotas, and sexual orientation and transgender rights as normative (Avdeyeva, 2010; Berkovitch, 1999; Fernández \& Lutter, 2013; Hughes, Krook, \& Paxton, 2015; Kollman, 2007; Krook \& True, 2012; Ramirez, Soysal, \& Shanahan, 1997; Swiss, $\&$ Fallon, 2017). ${ }^{1}$ The question is, have gender equality norms to support women, children, and families and to help balance work and family life become embedded in domestic policies and institutions? And has the status of women, children, and families improved directly because of international norm setting? After, all, as Zwingel notes with regard to gender equality, "As many violations of women's rights are rooted in sociocultural traditions and perpetrators are often nonstate actors, such violations were long seen as a problem to be solved by incremental change from within a given society, not by international interference or even pressure" (2012, p. 116). So, does the work of supranational actors in general, and IOs in particular make a difference? Why would we expect that they would?

Simmons et al. (2008, p. 10) examine the processes by which ideas diffuse and become embedded institutionally. They argue that transnational diffusion of policy ideas occurs as the result of four mechanisms: competition, coercion, socialization/learning, and emulation. Governments may

\footnotetext{
${ }^{1}$ Norms are defined as collective expectations of "right" or "appropriate" action characteristic of particular actors (Jurkovich, 2019, p. 2).
} 
adopt similar policy ideas as an instrumentally rational means to compete with other countries economically. Governments may also experience coercion from leading or powerful countries which can encourage or even impose policy harmonization. It is thus important to observe countries' position in the world order. Governments may be persuaded to adopt a particular policy because they come to believe it is the "right" thing to do, for example, in order to be seen as "modern" (Meyer, Boli, Thomas, \& Ramirez, 1997). Alternatively, states may "actively assess the content of a particular message - a norm, practice, or belief - and 'change their minds" in a process of learning (Goodman \& Jinks, 2013, p. 22). As Greenhill (2010, p. 128) argues, policy leaders such as IOs or leading states can use economic and other sanctions to encourage cooperation and punish norm violators. While the former processes can be described as socialization or "learning" through persuasion, where states add new information to prior knowledge and beliefs to revise their assessments, the latter process is more akin to coercion. Finally, states may simply "follow the leader" and emulate, that is, imitate the most powerful or successful actors. Emulation may be deliberate, as a means to increase one's standing in the world without significant costs, or a process of more "blindly" adopting the "beliefs and behavioral patterns of the surrounding culture, without actively assessing the merits of those beliefs and behaviors or the material costs and benefits of conforming to them" (Goodman \& Jinks, 2013, p. 22). Emulation can also work in the opposite direction: one country may be tempted to opt out of a practice if others have adopted it. In other words, emulation on the part of some states could lead, in the end, to greater policy divergence (Encarnación, 2017).

These processes of policy diffusion can simply involve government-togovernment transfers of ideas, norms, and best practices-after all, we know that policy decisions take place in conditions of state interdependence and decisions taken by one government alter "the conditions under which other governments make their decisions" (Elkins, 2009, p. 49)—or they can be explicitly facilitated by IOs. The sheer number of meetings of "first ministers" in intergovernmental forums has proliferated over the past fifty years (Greenhill, 2010), enabling policymakers from various countries to interact more than ever and facilitate government-to-government learning and policy convergence (Boushey, 2010; Drezner, 2005).

Beyond state-to-state policy transfer, however, are other principal agents of diffusion, including transnational advocacy networks, "distinguishable largely by the centrality of principled ideas or values motivating their formation" (Keck \& Sikkink, 1998, p. 1) and transnational epistemic communities, communities of experts rooted in shared scientific models who articulate 
"cause-and-effect relationships of complex problems," and who share their ideas with each other and with policy makers (Haas, 1992, p. 2). International organizations are also key organizations that help to facilitate the spread of common practices amongst member countries. The question is what are IOs' sources of authority and what kinds of governance functions do they perform. After all, the traditional role of IOs and IGOs are to facilitate interstate interactions, promote collective interests, and provide services such as data collection on behalf of states, not to be domestic lawmakers. Thus, an important research question is whether and to what extent IOs affect domestic policy development.

Barnett and Finnemore (2004) outline the sources of IO authority, including the strongest source, conditionality, which requires states to alter domestic policy in exchange for funding. Such is the case with regard to the International Monetary Fund and World Bank. Other sources of authority include facilitating the negotiation of treaties and conventions that bind countries that ratify, such as UN human rights conventions. Finally, some IOs are authoritative because of their perceived legitimacy on economic and other policy matters and expertise, such as in the case of the OECD (see also Jenson in this volume).

In most matters to do with social and family policy, IOs rarely have the authority to exercise "harder" forms of power. Greenhill notes that the European Union has the power to motivate countries that wish to join the EU to, for example, comply with human rights practices, but that "this type of coercively induced human rights improvement seems to be more the exception than the rule" (2010, p. 129) with regard to IOs. De la Porte notes that the EU has the power to regulate- that is, set legal standards and norms at the EU level—and to facilitate "hard" coordination—that is, "EU-facilitated policy coordination that is legally binding and the involves high surveillance and enforcement of member state policy" (2018, p. 478). But it does not have the authority to "decide upon national social security, the principles of distribution, and the access to social rights or the level of generosity of various benefits" (De la Porte, 2018, p. 478). De la Porte argues that EU regulations - in the form of directives - can certainly contribute to policy coordination in the area of social policy, mobility rights and the movement of works, anti-discrimination, and even the labor market given EU directives on minimum maternity and parental leave standards. Still others argue that "softer" tools at IOs' disposal can be persuasive (Kollman, 2009). Soft power refers to the ability of IOs to exert influence through the establishment of norms that socialize actors toward compliance, as well as processes of persuasion and learning, that is, the proffering of policy models or "best practices." 
Furthermore, IOs such as the OECD are also sources of expert knowledge (Barnett \& Finnemore, 2004) and can engage in softer forms of governance such as peer review - the assessment of policies - and surveillance - the monitoring of compliance with agreed to conventions and rules.

Another question is whether domestic policy advocates find the international arena useful in pressing their policy agenda. Poloni-Staudinger and Ortbals (2014) find empirical evidence that in fact women's groups still target domestic levels of government more so than the international leveleven when the issues for which they advocate are more transnational than domestic. They are only more likely to focus attention on the international level when the domestic political opportunity structure seems less hospitable because of electoral cleavages and low alliance possibilities.

International norms, though, can have a "boomerang effect" in that they can serve as resources for domestic and transnational policy actors to pressure governments through supranational forums (Krook \& True, 2012, p. 107). Finally, norms are not simply constructed but also debated and challenged. There is thus a discursive element to their creation and evolution that can be "revealed by repeated speech acts" (Krook \& True, 2012, p. 105). The process of international norm setting can therefore be a key domestic discursive instrument that through the very act of their discussion and debate change actors' perspectives on an issue.

\section{How Easily Are Ideas Translated from the International to the Domestic Policy Arena? A Review of Empirical Research}

Empirical research demonstrates that norms tend to be imperfectly transmitted from the international to the domestic level and enacted into law and policy (Linos, 2013; Orenstein, 2008; Risse-Kappen, 1994; Weyland, 2006). One limitation is whether states regard transnational advocates, epistemic communities, and IOs as sources of legitimate policy advice. Some country governments may regard the authority of international organizations with suspicion. Other governments may contest the legitimacy of norms.

Domestic uptake of international and transnational ideas and norms is thus contingent on a number of interactive factors - what Risse and Sikkink (1999) label a "spiral model" of contingent change. Domestic institutions and electoral coalitions in government may create veto points that make the transfer of policy ideas difficult (Tsebelis, 1995). For example, the political elite at one level or branch of government may embrace a particular idea, but 
competing elites either within another branch of government or at another level of government in a federal system may act as "veto players"-someone whose agreement is needed in order to proceed (Tsebelis, 1995). So too can recalcitrant bureaucracies (Patashnik, 2008). Partisan shifts in key political decision makers, such as after an election, may stymie the adoption of a policy with which a previous electoral coalition found favor. Opposition interest groups may also respond negatively to policy initiatives that were generated at the supranational level. Policy makers may thus back away from their international commitments for fear of electoral loss. All these factors can impede the transfer and uptake of international ideas and norms in any domestic policy setting.

\section{International and Transnational Influences on Gender Equality}

What is the record of success in the area of gender equality policy generally and family equality in particular? A number of researchers have examined the domestic policy impact of international human rights norms negotiated between states and articulated in treaties and conventions, ${ }^{2}$ such as the UN Convention on the Elimination of All Forms of Discrimination Against Women (CEDAW) (Raday, 2012; Zwingel, 2012). CEDAW was adopted in 1979 by the UN General Assembly and was ratified by 187 states. It establishes an international regime with both a regulative dimension-in the form of standard setting - and a constitutive dimension - in the sense that it identifies principles of "right" action for states. The goals articulated in the convention are the "elimination of discrimination against women, achievement of gender equality, and state responsibility" (Zwingel, 2012, p. 117). By ratifying, "states agree to eliminate direct and indirect forms of discrimination against women in any field of life" (Zwingel, 2012, p. 117). The expert committee of CEDAW monitors state performance with regard to the protection and fulfillment of women's rights.

The convention covers a wide range of gender-based inequality concerns including addressing formally discriminatory treatment and recognizes intersectionality brought by poverty, membership in minority groups, and so on. Raday argues that the ratification of CEDAW signals "considerable achievements" including "international recognition of women's rights as human rights, creation of a national machinery for the advancement of women,

\footnotetext{
${ }^{2}$ For research on the UN convention on the rights of the child see, for example, Boyle and Nyseth (2011) and Brehm and Boyle (2018). See White (2014) on Canada's abysmal implementation record.
} 
collection of sex-disaggregated data by states parties, promotion of transnational social movements [TSMs] for women's political participation, and enactment of specific domestic violence legislation" (2012, p. 516). But the norms articulated in the Convention also compete with norms around states' religious and cultural autonomy and the structural realities of economic globalization where women remain disproportionately in occupations that are not as well remunerated, where they are more likely to live in poverty, and be subject to human trafficking. Furthermore, both Raday (2012, p. 516) and Zwingel (2012) note that CEDAW is one of the most "heavily reserved of the international human rights treaties" particularly regarding religious reservations. A process exists by which individuals can bring complaints and independent inquiries if a state is accused of violating their responsibilities under the Convention. But the remedy is soft pressure or shaming, not coercion.

Zwingel (2012) thus offers a more contextualized assessment of the influence of CEDAW. She argues that "transnational, national, and local dynamics need to be taken seriously to understand the relevance of international institutions" (Zwingel, 2012, p. 115). International human rights regimes are what Zwingel (2012, p. 115) calls "promotional"-i.e., fixing the "ought"; but rights implementation is largely a domestic affair with a number of domestic factors that affect implementation, including competing norms. Thus, ratification of an international human rights treaty is only "one step on a long path to the realization of these rights" (Zwingel, 2012, pp. 115-116).

Other examples of uneven implementation of international norms include women's right to equality of political office holding, and gender mainstreaming (Krook \& True, 2012; Paxton et al., 2006; Swiss \& Fallon, 2017). The UN, for example, has provided an important forum to push for women's equal rights to political office holding. States adopted the Convention on the Political Rights of Women in the UN General Assembly in 1946, although it was not unanimous and many states reserved the right not to abide by provisions in the Convention (Krook \& True, 2012, p. 113). The UN Beijing Platform for Action in 1995 set more specific targets for women's representation at $30 \%$ in political office. Those targets gradually expanded to recognize the importance of diversity in office holding, including in the political executive (Jacob, Scherpereel, \& Adams, 2014) and the composition of office holders in UN bodies themselves (Krook \& True, 2012). Gender mainstreaming norms do not set specific targets but rather prescribe a normative standard and practice of assessing the gendered impact of planned laws, public policies, and programs. As Krook and True (2012) note, "regulative" 
norms such as gender mainstreaming, while prescriptive, are also fluid enough to allow for variation in adoption.

Research has identified some of the important factors that affect norm uptake domestically: whether domestic governments have an interest and principled commitment to their implementation, which in turn is affected by the partisan composition of governing coalitions and domestic cultural values (Fernández \& Lutter, 2013); whether there are robust non-state actors and activity at both the domestic and transnational level to advance equality concerns (Hughes et al., 2015); and whether a significant number of women hold elected office (Avdeyeva, 2010). Boyle, Kim, and Longhofer (2015) find that domestic factors, such as the number of women in parliament, are at least as predictive to abortion liberalization as international factors such as the extent to which countries are deeply embedded in what Meyer et al. (1997) label "world society." 3 Boyle et al. (2015) operationalize the latter as the extent of state participation in women's rights INGOs and treaty signing. Kollman (2009) observes, in contrast, that a transnational network of LGBT actors and organizations, along with various European institutions led to a dramatic change in family policy around relationship recognition in a number of European countries over the past couple of decades. Kollman, however, attributes the changes not to legally binding EU mandates but rather to the creation of a soft law norm "cobbled together from a serious of resolutions by the EP [European Parliament], the incorporation of sexual orientation into the Treaty of Amsterdam's anti-discrimination clause, provided by Nordic states, and key decisions by the ECHR [European Court of Human Rights] to eliminate other forms of sexual orientation-based discrimination" (2009, p. 51). Yet, the unevenness in adoption throughout Europe "suggests that pressure for same-sex relationship recognition is filtered through domestic mediating factors" such as governing coalitions (Kollman, 2009, p. 51). Kollman's research also highlights the difficulties faced in attempting to impose harder laws when domestic government coalitions have not internalized core principles "particularly in policy fields, such as family policy, that are highly politicized" (2009, p. 51). Hughes et al. (2015, p. 358) also find a "recoiling effect" by some states in the face of normative pressures and thus a lesser likelihood of adoption, especially in response to highly contested global norms such as gender equality.

\footnotetext{
3"World society" scholars such as Meyer et al. (1997) posit that global norms are important drivers of state action because state actors that participate in those institutions are shaped and constrained by the global norms they encounter about what it means to be "modern".
} 


\section{International and Transnational Influences on Domestic Family Policy}

The verdict is similarly mixed regarding the international and transnational influences on domestic policies such as family policy. White (2017b), for example, finds that in the area of maternity and parental leave expansion over the past two decades in Australia, New Zealand, and the United Kingdom IOs played less of a role than expected in benefits adoption/expansion, despite an EU directive and policy attention by other IOs including the ILO and OECD. Indeed, the Australian government had ratified CEDAW in 1983 but reserved the provision regarding maternity leave provision (White, 2017b, p. 62). The UK did not opt into the EU Parental Leave Directive until after the election of the Labor government under Tony Blair. Instead, domestic policy pressures to increase maternal employment, as well as political factors such as the election of center-left governments and interest group activism were found to be more influential. IOs' influence appears to include setting international benchmarks through reports and other policy documents that could be used by domestic actors to push for policy change-what Blyth (2001) calls "blueprints" for action. But, unlike world society scholars such as Meyer et al. (1997) assertion, "IOs' work and the ideas promoted did not create cognitive locks in these countries, where the ideas would be emulated simply because they were perceived as normatively 'good'" (White, 2017b, p. 58).

Other research has demonstrated that domestic political institutions, such as decentralized decision making arising from federalism (Banting \& Myles, 2013) or principles of subsidiarity (Gray, 2010), political coalition formation-particularly alliances with left parties and labor unions (Korpi, 2006) — and welfare regimes (Esping-Andersen, 1990) matter; as do institutional path dependencies created by electoral institutions and political economic structures (Iversen \& Soskice, 2009). As the literature on gender equality in general notes, so too does governing party ideology, cultural norms regarding the role of the state vis-à-vis the family, and the strength of both conservative public opinion and mobilized opposition to public investments (White, 2017a).

This is not to say that transnational norm development has no role to play. As Jenson's chapter in this volume notes, particularly in the EU context, the European Commission and related organizations played a large role in developing and shaping family policy and programs in response to a variety of member state concerns: population decline as well as an ageing population, income security, maternal employment, and reconciliation of work 
and family life. The EU has issued a number of directives around pregnancy and parental leave and workplace anti-discrimination and women's employment and child care service targets. And De la Porte (2018) notes an explicit dual-earner labor market norm has permeated EU policies over the last two decades (in contrast to the male breadwinner norm of the past). These ideas and policy goals were not exclusive to EU institutions, however. The counterfactual question is whether, in the absence of the EU whether countries would be driven to respond to labor market, population, and income security concerns regardless.

Those domestic policy agendas - and the factors that influence themare also important to observe. Morgan (2005), for example, tracks the relationship between varieties of capitalism - that is, the organization of principal economic and labor market institutions and the ongoing relationships between the state, employers, and employees—and public investments in human capital supportive policies and programs such as child care. Coordinated market economies tend to provide more extensively subsidized child care for families, in contrast to liberal market economies/liberal welfare states. In the latter countries, "labour markets are deregulated, workers lack job protection and generous unemployment benefits" and there is high turnover in employment (Morgan, 2005, p. 245). Such employment conditions create a pool of low-wage workers for service occupations such as child care. In many European coordinated market economies, a more highly regulated labor market increases the costs of labor. Governments therefore generally take the path exemplified in social democratic countries such Sweden and publicly provide child care with labor market rules that generate a highly skilled and well-paid often unionized child care workforce. Or governments such as France take a more regulatory route and provide policies to help reconcile work and family life to ensure employment is compatible with care.

Traditional patterns of state investment in family policy are changing, however, in a number of OECD countries. Daiger von Gleichen and SeeleibKaiser (2018), for example, observe that in a number of OECD countries, public policies have generally shifted away from the male breadwinner model toward support for dual earner households and to help reconcile tensions between work and family. While the early adopters were largely driven by the normative aim of gender equality and assisted in realizing those goals with the support of a strong women's movement, and strong representation in parliament, other countries have adopted family-friendly policies without strong social democratic parties or a strong women's movement. Daiger von Gleichen and Seeleib-Kaiser (2018) argue that more instrumental reasoning, 
such as improving the use of human capital through increased female employment or addressing demographic challenges are key drivers (see also Ferragina \& Seeleib-Kaiser, 2015; Fleckenstein \& Seeleib-Kaiser, 2011).

An important research agenda is emerging on the expansion of social investment policies and programs across a number of countries around the world (Garritzmann, Häusermann, Palier, \& Zollinger, 2017; Hemerijck, 2017). Less world society and more the functional imperative of labor markets, countries such as Germany are overcoming traditional reticence to maternal employment to enact sweeping family policy reforms (Blome, 2017; Morgan, 2013). Garritzmann et al. argue, "The social investment perspective emphasizes the necessity to invest in human capital, to mobilize and to renew it along the entire life course in order to accompany the demands of changing production systems, and to address the new social risks not met by the old welfare state" $(2017$, p. 2). As Morel et al. argue, they include such policies and programs that "invest in human capital development (early childhood education and care, education and life-long training) and that help to make efficient use of human capital (through policies supporting women's and lone parents' employment, through active labor market policies, but also through specific forms of labor market regulation and social protection institutions that promote flexible security), while fostering greater social inclusion (notably by facilitating access to the labor market for groups that have traditionally been excluded)" (Morel, Palier, \& Palme, 2012, p. 2)

Some scholars argue that the adoption and/or expansion of this basket of policies and programs represents a new paradigm, complementing and in some ways competing with traditional compensatory policies (Hemerijck, 2018; Häusermann, 2018). At the same time, a great deal of variation can be observed in the scope and depth of social investment between and within countries. For example, among the liberal welfare states, governments have expanded public funding for child care in the UK, Australia, and New Zealand much more than in the USA and Canada (White, 2017a). Despite the typical drag that federal institutions and conservative politics play in stymieing social policy investments, the German government under Angela Merkel has made significant child care investments (Blome, 2017; Morgan, 2013). These social investments are driven by electoral calculations as well as the growing significance of women in political parties, according to Morgan (2013). It is worth noting that international norms and standard setting are not considered as salient explanatory factors. Instead, the welfare state "is a power resources that politicians seek to deploy for electoral purposes" (Morgan, 2013, p. 74). 
While women's elected representatives, interest groups, and center-left party coalitions have been key factors in the social investment turn and support for work-family reconciliation policies, the decline of labor, and labor's attachment to left parties, have led both center-right and left party coalitions in a number of countries in Europe and elsewhere to flirt with policies and programs that aim to gain the support of "natives" over newcomers (Gingrich \& Häusermann, 2015; Schumacher \& Van Kersbergen, 2016). At the same time, challenges have arisen to welfare models based on universal entitlement, as a changing pool of recipients draws on benefits; and on to the dual-earner model which has only recently shifted from the male breadwinner model of employment (Grødem, 2017). A future area of research is to examine the diffusion of ideas around has been labeled "welfare nationalism" or "welfare chauvinism," in conjunction or in competition with traditional coalition tactics and social investment policies, as well as the role that IOs such as the EU can play in tempering radical chauvinism.

\section{Conclusion}

As Krook and True (2012, p. 106) note, the trajectory of norms is "fraught with contestation and reversals as state and non-state actors compete to identify, define and implement" norms. Thus, it is very helpful to think of norms as processes rather than as things. This chapter documents some of those norms around gender equality, rights around family formation, and family policy, especially around policies such as child care and parental leave that help reconcile work and family life. While these norms around the "oughts" of family support are increasingly advanced by IOs and EU member states, the attendant laws and policies are subject to continuing contestation and change and myriad sources of ideational influence, including ideas generated at the international level. But domestic coalitions of political actors and organizations are key to implementation, as other chapters in this volume document.

\section{References}

Avdeyeva, O. (2010). States' compliance with international requirements: Gender equality in EU enlargement countries. Political Research Quarterly, 63(1), 203217.

Banting, K., \& Myles, J. (2013). Introduction. In K. Banting \& J. Myles (Eds.), Inequality and the fading of redistributive politics (pp. 1-39). Vancouver, Canada: University of British Columbia Press. 
Barnett, M., \& Finnemore, M. (2004). Rules for the world: International organizations in global politics. London: Cornell University Press.

Berkovitch, N. (1999). From motherhood to citizenship: Women's rights and international organizations. Baltimore, MD: Johns Hopkins University Press.

Blome, A. (2017). The politics of work-family policy reforms in Germany and Italy. New York, NY: Routledge.

Blyth, M. (2001). The transformation of the Swedish model: Economic ideas, distributional conflict, and institutional change. World Politics, 54(1), 1-26.

Boushey, G. (2010). Policy diffusion dynamics in America. New York: Cambridge University Press.

Boyle, E. H., Kim, M., \& Longhofer, W. (2015). Abortion liberalization in World Society, 1960-2009. American Journal of Sociology, 121(3), 882-913.

Boyle, E. H., \& Nyseth, H. (2011). Why the underutilization of child rights in global mobilization? The case of female genital cutting practices and user fees for education. In A. Sarat (Ed.), Special issue human rights: New possibilities/new problems (Studies in Law, Politics and Society, Vol. 56, pp. 91-119). Bingley: Emerald Group Publishing Limited.

Brehm, H. N., \& Boyle, E. H. (2018). The global adoption of national policies protecting children from violent discipline in schools and homes, 1950-2011. Law \& Society Review, 52(1), 206-233.

Council Directive. 2010/18/.EU implementing the revised framework agreement on parental leave concluded by BUSINESSEUROPE, UEAPME, CEEP and ETUC and repealing Directive 96/34/EC (Text with EEA relevance) OJ L 68, 18.3.2010, (pp. 13-20).

Council Directive PE-CONS 20/19. Directive of the European parliament and of the council on work-life balance for parents and carers and repealing council directive 2010/18/EU. Online: https://www.consilium.europa.eu/en/press/press-releases/ 2019/06/13/better-work-life-balance-for-parents-and-carers-in-the-eu-counciladopts-new-rules/.

De la Porte, C. (2018). EU social policy and national welfare state reform. In B. Greve (Ed.), The Routledge handbook of the welfare state (2nd ed., pp. 477-487). London and New York: Routledge.

Drezner, D. W. (2005). Globalization, harmonization, and competition: The different pathways to policy convergence. Journal of European Public Policy, 12(5), 841-859.

Elkins, Z. (2009). Constitutional networks. In M. Kahler (Ed.), Networked politics: Agency, power, and governance (pp. 43-63). Ithaca, NY: Cornell University Press.

Encarnación, O. G. (2017, May 2). The global backlash against gay rights. Foreign Affairs. Online: https:/www.foreignaffairs.com/articles/2017-05-02/glo bal-backlash-against-gay-rights.

Esping-Andersen, G. (1990). The three worlds of welfare capitalism. Princeton, NJ: Princeton University Press. 
Fernández, J. J., \& Lutter, M. (2013). Supranational cultural norms, domestic value orientations and the diffusion of same-sex union rights in Europe, 1988-2009. International Sociology, 28(1), 102-120.

Ferragina, E., \& Seeleib-Kaiser, M. (2015). Determinants of a silent (r)evolution: Understanding the expansion of family policy in rich OECD countries. Social Politics: International Studies in Gender, State \& Society, 22(1), 1-37.

Fleckenstein, T., \& Seeleib-Kaiser, M. (2011). Business, skills and the welfare state: The political economy of employment-oriented family policy in Britain and Germany. Journal of European Social Policy, 21(2), 136-149.

Garritzmann, J. L., Häusermann, S., Palier, B., \& Zollinger, C. (2017). WoPSIThe world politics of social investment: An international research project to explain variance in social investment agendas and social investment reforms across countries and world regions. (LIEPP Working Paper No. 64). SciencesPo. Online: https:// doi.org/10.5167/uzh-142576.

Gingrich, J., \& Häusermann, S. (2015). The decline of the working-class vote, the reconfiguration of the welfare support coalition and consequences for the welfare state. Journal of European Social Policy, 25(1), 50-75.

Goodman, R., \& Jinks, D. (2013). Socializing states: Promoting human rights through international law. Oxford: Oxford University Press.

Gray, G. (2010). Federalism, feminism and multilevel governance: The elusive search for theory? In M. Haussman, M. Sawer, \& J. Vickers (Eds.), Federalism, feminism, and multilevel governance (pp. 19-33). London: Routledge.

Greenhill, B. (2010). The company you keep: International socialization and the diffusion of human rights norms. International Studies Quarterly, 54(1), 127145.

Grødem, A. S. (2017). Family-oriented policies in Scandinavia and the challenge of immigration. Journal of European Social Policy, 27(1), 77-89.

Haas, P. M. (1992). Introduction: Epistemic communities and international policy coordination. International Organization, 46(1), 1-35.

Häusermann, S. (2018). The multidimensional politics of social investment in conservative welfare regimes: Family policy reform between social transfers and social investment. Journal of European Public Policy, 25(6), 862-877.

Hemerijck, A. (Ed.). (2017). The uses of social investment. Oxford, UK: Oxford University Press.

Hemerijck, A. (2018). Social investment as a policy paradigm. Journal of European public policy, 25(6), 810-827.

Hughes, M. M., Krook, M. L., \& Paxton, P. (2015). Transnational women's activism and the global diffusion of gender quotas. International Studies Quarterly, 59(2), 357-372.

Iversen, T., \& Soskice, D. (2009). Distribution and redistribution: The shadow of the nineteenth century. World Politics, 61(3), 438-486.

Jacob, S., Scherpereel, J. A., \& Adams, M. (2014). Gender norms and women's political representation: A global analysis of cabinets, 1979-2009. Governance, $27(2), 321-345$. 
Jurkovich, M. (2019). What isn't a norm? Redefining the conceptual boundaries of "norms" in the human rights literature. International Studies Review. Advance articles. https://doi.org/10.1093/isr/viz040.

Keck, M. E., \& Sikkink, K. (1998). Activists beyond borders: Advocacy networks in international politics. Ithaca, NY: Cornell University Press.

Klotz, A. (1995). Norms in international relations: The struggle against apartheid. London, Ithaca, NY: Cornell University Press.

Kollman, K. (2007). Same-sex unions: The globalization of an Idea. International Studies Quarterly, 51(2), 329-357.

Kollman, K. (2009). European institutions, transnational networks and national same-sex unions policy: When soft law hits harder. Contemporary Politics, 15(1), 37-53.

Korpi, W. (2006). Power resources and employer-centered approaches in explanations of welfare states and varieties of capitalism: Protagonists, consenters, and antagonists. World Politics, 58(2), 167-206.

Krook, M. L., \& True, J. (2012). Rethinking the life cycles of international norms: The United Nations and the global promotion of gender equality. European Journal of International Relations, 18(1), 103-127.

Linos, K. (2011). Diffusion through democracy. American Journal of Political Science, 55(3), 678-695.

Linos, K. (2013). The democratic foundations of policy diffusion: How health, family, and employment laws spread across countries. Oxford and New York: Oxford University Press.

Marsh, D., \& Sharman, J. C. (2009). Policy diffusion and policy transfer. Policy Studies, 30(3), 269-288.

Meyer, J. W., Boli, J., Thomas, G. M., \& Ramirez, F. O. (1997). World society and the nation-state. American Journal of Sociology, 103(1), 144-181.

Morel, N., Palier, B., \& Palme, J. (2012). Beyond the welfare state as we knew it? In N. Morel, B. Palier, \& J. Palme (Eds.), Towards a social investment welfare state? Ideas, policies and challenges (pp. 1-30). Bristol, UK: Policy Press.

Morgan, K. J. (2005). The "production" of child care: How labor markets shape social policy and vice versa. Social Politics: International Studies in Gender, State \& Society, 12(2), 243-263.

Morgan, K. J. (2013). Path shifting of the welfare state: Electoral competition and the expansion of work-family policies in Western Europe. World Politics, 65(1), $73-115$.

Orenstein, M. (2008). Privatizing pensions: The transnational campaign for social security reform. Princeton, NJ: Princeton University Press.

Patashnik, E. M. (2008). Reforms at risk: What happens after major policy changes are enacted. Princeton: Princeton University Press.

Paxton, P., Hughes, M. M., \& Green, J. L. (2006). The international women's movement and women's political representation, 1893-2003. American Sociological Review, 71(6), 898-920. 
Payne, R. A. (2001). Persuasion, frames and norm construction. European Journal of International Relations, 7(1), 37-61.

Poloni-Staudinger, L., \& Ortbals, C. (2014). The domestic determinants of transnational activity: An examination of women's groups in the United Kingdom, France, and Germany. International Studies Quarterly, 58(1), 68-78.

Raday, F. (2012). Gender and democratic citizenship: The impact of CEDAW. International Journal of Constitutional Law, 10(2), 512-530.

Ramirez, F. O., Soysal, Y., \& Shanahan, S. (1997). The changing logic of political citizenship: Cross-national acquisition of women's suffrage rights, 1890-1990. American Sociological Review, 62(5), 735-745.

Risse, T., \& Sikkink, K. (1999). Introduction. In T. Risse, S. C. Ropp, \& K. Sikkink (Eds.), The power of human rights: International norms and domestic change (pp. 138). Cambridge and New York: Cambridge University Press.

Risse-Kappen, T. (1994). Ideas do not float freely: Transnational coalitions, domestic structures, and the end of the cold war. International Organization, 48(2), 185214.

Schumacher, G., \& Van Kersbergen, K. (2016). Do mainstream parties adapt to the welfare chauvinism of populist parties? Party Politics, 22(3), 300-312.

Simmons, B. A., Dobbin, F., \& Garrett, G. (Eds.). (2008). The global diffusion of markets and democracy. New York: Cambridge University Press.

Slaughter, A.-M. (2004). A new world order. Princeton: Princeton University Press.

Swiss, L., \& Fallon, K. M. (2017). Women's transnational activism, norm cascades, and quota adoption in the developing world. Politics \& Gender, 13(3), 458-487.

Tsebelis, G. (1995). Decision making in political systems: Veto players in presidentialism, parliamentarism, multicameralism and multipartyism. British Journal of Political Science, 25(3), 289-325.

Von Gleichen, D. R., \& Seeleib-Kaiser, M. (2018). Family policies and the weakening of the male-breadwinner model. In S. Shaver (Ed.), Handbook on gender and social policy (pp. 153-178). Cheltenham, UK: Edward Elgar.

Weyland, K. (2006). Bounded rationality and policy diffusion: Social sector reform in Latin America. Princeton, NJ: Princeton University Press.

White, L. A. (2011). The internationalization of early childhood education and care issues: Framing gender justice and child well-being. Governance, 24(2), 285-309.

White, L. A. (2014). Understanding Canada's lack of progress in implementing the UN convention on the rights of the child: The intergovernmental dynamics of children's policy making in Canada. The International Journal of Children's Rights, 22(1), 164-188.

White, L. A. (2017a). Constructing policy change: Early childhood education and care in liberal welfare states. Toronto: University of Toronto Press.

White, L. A. (2017b). Which ideas, whose norms? Comparing the relative influence of international organizations on paid maternity and parental leave policies in 
liberal welfare states. Social Politics: International Studies in Gender, State \& Society, 24(1), 55-80.

Zwingel, S. (2012). How do norms travel? Theorizing international women's rights in transnational perspective. International Studies Quarterly, 56 (1), 115-129.

Open Access This chapter is licensed under the terms of the Creative Commons Attribution 4.0 International License (http://creativecommons.org/licenses/by/4.0/), which permits use, sharing, adaptation, distribution and reproduction in any medium or format, as long as you give appropriate credit to the original author(s) and the source, provide a link to the Creative Commons licence and indicate if changes were made.

The images or other third party material in this chapter are included in the chapter's Creative Commons licence, unless indicated otherwise in a credit line to the material. If material is not included in the chapter's Creative Commons licence and your intended use is not permitted by statutory regulation or exceeds the permitted use, you will need to obtain permission directly from the copyright holder.

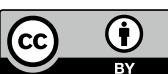

